\title{
HEAVY METAL CONTENT AND LOCALIZATION IN MYCORRHIZAL EUPHORBIA CYPARISSIAS FROM ZINC WASTES IN SOUTHERN POLAND
}

\author{
KATARZYNA TURNAU \\ Institute of Botany of the Jagiellonian University, \\ ul. Lubicz 46, 31-512 Kraków, Poland
}

(Received: January 30, 1998. Accepted: February 20, 1998)

\begin{abstract}
Arbuscular mycorrhiza (AM) development, heavy metal uptake by the plant and localization of heavy metals within plant and AM fungal structures, has been investigated in Euphorbia cyparissias collected from zinc wastes in Poland and from two other stands differing in soil parameters. The plant was selected on the basis of preliminary research on mycorrhiza of plants colonizing zinc wastes. E. cyparissias was strongly mycorrhizal and arbuscules were abundant except at the very beginning of the vegetation period. Light microscopy after rhodizoniate staining and SEM equiped with an EDS system have been used to localize heavy metals within the fungal mycelium and mycorrhizal roots. About $80 \%$ of the total intraradical mycelium show an increased content of heavy metals in comparison to the remaining $20 \%$ where heavy metals were under detection limit. At the same time the number of arbuscules formed by mycelium stained by rhodizoniate is slightly lower than in mycelium containing a low level of these elements. Using the rhodizoniate staining lead was found in epidermal cell walls, root hairs, in mycorrhizal mycelium and in crystaloids deposited within latex and inside cortical cells, around fungal hyphae. SEM observations with EDS system confirmed that these crystaloid depositions contained higher concentrations of $\mathrm{Zn}$ than root cell wall and fungal structures.
\end{abstract}

KEY WORDS: arbuscular mycorrhiza, element uptake, Euphorbia cyparissias L., heavy metals, industrial wastes.

\section{INTRODUCTION}

Metal bearing industrial wastes pose a serious environmental threat. The zinc industry, which is especially active in southern region of Poland, produces tons of wastes every year which are often deposited close to areas inhabited by people. The wastes are usually a very poor plant-growth medium. It is devoid of adequate levels of organic matter, nitrogen and phosphorus, as well as having a very low water-holding capacity. Due to high wind erosion of the substratum there is an urgent need for plant introduction into such areas. Though mycorrhizas are known as a potentially important agent in the improvement of plant growth and in heavy metal detoxification, available data on the mycorhizal status of plants appearing in highly polluted areas are conflicting (Leyval et al. 1997). In some cases the delay, reduction or even elimination of mycorrhizal colonization has been found (Gildon and Tinker 1983; Graham et al. 1986; McGee 1987; Koomen et al. 1990; Chao and Wang 1991; Leyval et al. 1991) while in others, high levels (sometimes even greater than in nonpolluted areas) of mycorrhizal colonization were observed (Weissenhorn et al. $1995 \mathrm{a}, \mathrm{b}$; Turnau et al. 1996). The lack of information on the bioavailability of heavy metals has been sugested as the main impediment to comparing the data (Leyval et al. 1997).
The effect of arbuscular mycorrhizal symbiosis on heavy metal uptake by plants has been studied in laboratory and natural conditions. Some reports show a higher uptake of metals by mycorrhizal plants at high metal concentrations of the soil (Gildon and Tinker 1983; Killham and Firestone1983; Weissenhorn and Leyval 1995), while others show a decreased heavy metal content attributed to mycorrhizal symbiosis (Schüepp et al. 1987; El-Kherbawy et al. 1989; Weissenhorn et al. 1995 a). In most of these studies, however, usually only the percentage of root colonization by mycorrhizal fungi is evaluated. Not much attention has been payed to the functional aspect of mycorrhizas, vitality, arbuscule development, nor is much known about the response of plants to fungal colonization in stressed conditions.

Investigation of revegetation processes on 25-year-old zinc wastes in Chrzanow near Cracow has shown that both nonmycorrhizal and mycorrhizal plants appear there. Within the second group, an important distinction was noted. Mycorrhizal development was much better (higher root colonization and much more abundant arbuscule formation) in case of E. cyparissias, which appeared naturally on zinc wastes, than in plant species as Hippophae rhamnoides and Arrhenatherum elatius which were artificially introduced as part of a program of recultivation. In the case of the last two species, which roots were analyzed monthly during two seasons, fungal 
colonization occasionally reached up to $50 \%$ of the root system, but the arbuscule formation was an exceptional case (unpublished data). Because mycorrhizal colonization of E. cyparissias roots was much higher than $H$. rhamnoides and A. elatius roots, it was selected for research devoted to understanding fungal and plant strategies on zinc wastes. For comparison, its mycorrhizal status was analyzed at two other sites differing in environmental parameters.

Localization and estimation of heavy metal content in mycorrhizal roots of E. cyparissias were the main aims of this paper. Two complementary methods were used: electron microscopy accompanied by energy dispersion system (localizing elements on the ultrastructural level) and conventional atomic absorption spectroscopy.

The rhodizoniate staining, a cytochemical indicator of lead at light microscopy level, was used here for the first time in mycorrhizal research. The main reason to employ this method was to select material for further research with light and electron microscope. The test has been applied before to localize lead in Stigeoclonium tenue (Silverberg 1975) in Cladophora (Theiss 1987) in lichens (Garty and Theiss 1990) and also in studies on lead translocation and localization in Alium cepa roots (Wierzbicka $1987 \mathrm{a}, \mathrm{b}$ ). The test relys on the specific reaction of sodium rhodizoniate with lead ions at $\mathrm{pH} 2.8$ resulting in precipitation of a scarlet lead rhodizoniates $\left(2 \mathrm{PbC}_{6} \mathrm{O}_{6} \cdot \mathrm{Pb}(\mathrm{OH})_{2} \cdot \mathrm{H}_{2} \mathrm{O}\right)$ (Feigl 1954, Glateer and Hernandez 1972). With an increase in $\mathrm{pH}$, rhodizoniate forms a violet complex but at the same time the specificity for lead decreases. At $\mathrm{pH}$ over 5 also $\mathrm{Zn}$ and $\mathrm{Cd}$ salts give similar reaction while the change of colour in presence of $\mathrm{Cu}$ was noticed only at $\mathrm{pH}$ over 10. Presence of any other elements so far tested did not lead to formation of scarlet precipitation.

\section{MATERIALS AND METHODS}

The investigations were carried out on 25-year-old industrial wastes located in Chrzanow (southern Poland, $30 \mathrm{~km}$ west of (racow). The solid fraction of the wastes from the Trzebionka zinc factory is deposited as sedimentation tanks
(Lekan and Piotrowska 1988). E. cyparissias was collected 25 years later from slopes of the sedimentation tanks where the mean $\mathrm{pH}$ value in $\mathrm{H}_{2} \mathrm{O}$ was 7.4. (Table 2). For comparison, two other locations (stand A - Kostrze and stand B Wierzbanowka Valley; both in close vicinity to Cracow) of the species were selected (Table 1,2). Total and extractable (in $1 \mathrm{~N} \mathrm{HCl}$ and $0.1 \mathrm{~N} \mathrm{Ca}\left(\mathrm{NO}_{3}\right)_{2}$ ) elements in soils were estimated with atomic absorption spectrometry (Nowosielski 1968; Weissenhorn et al. 1995 b), $\mathrm{N}$ by the Kjeldahl method and organic matter by the Tiurin method. The shoots of $E$. cyparissias were collected every two weeks during 1995 and once a month during 1996. A part of the material was washed, dried, ground, and following mineralization (Grodzinska 1978), the element content of the plants was estimated using AAS (spectrophotometer Phillips PU-9100x). In case of roots and rhizomes only one composite sample for each stand was analyzed after careful rinsing.

For estimation of mycorrhizal colonization, the roots were prepared according to the modified method of Philips and Hayman (1970). E. cyparissias roots, following careful washing with tap water, were softened using $7 \% \mathrm{KOH}$ in water bath at $60^{\circ} \mathrm{C}$, washed again with water, bleached in $\mathrm{H}_{2} \mathrm{O}_{2}$ containing $\mathrm{NH}_{3}(10: 1)$ for a few minutes, washed again in water, acidified in $5 \%$ lactic acid in water for $12-24 \mathrm{~h}$, stained with $0.01 \%$ cotton blue in lactic acid (either for $1 \mathrm{~h}$ at $60^{\circ} \mathrm{C}$ or for $24 \mathrm{~h}$ at room temperature) and finally stored in lactic acid. Mycorrhizal frequency (F\%), mycorrhizal root length $(\mathrm{M} \%)$ and arbuscular richness $(\mathrm{A} \%)$ were assessed (Trouvelot et al. 1986). Analysis of variance (ANOVA, $\alpha=0,05$ ) and an a posteriori Duncans test were used to compare data, after arcsin tranformation.

Soil samples were also taken from the same locations and the spores of Glomales were selected by wet sieving and centrifugation in a sucrose gradient (Tommerup 1992). Spores were examined and morphotypes were isolated using a stereomicroscope. No further attempt were made to identify the species. A few spores of each morphotype were mounted in PVLG and some were used for a rhodizoniate test, described below, or for analysis by SEM equiped with EDS.

TABLE 1. Total and extractable (in $1 \mathrm{~N} \mathrm{HCl}$ and in $\mathrm{Ca}\left(\mathrm{NO}_{3}\right)_{2}$ ) heavy metal content in zinc wastes, stand $\mathrm{A}$ and $\mathrm{B}$ as analyzed from samples collected underneath E. cyparissias.

\begin{tabular}{|l|r|c|c|c|c|c|c|c|c|c|c|c|}
\hline & \multicolumn{3}{|c|}{$\mathrm{Zn}$} & \multicolumn{3}{c|}{$\mathrm{Pb}$} & \multicolumn{3}{c|}{$\mathrm{Cd}$} & \multicolumn{3}{c|}{$\mathrm{Cu}$} \\
\hline & total & $\begin{array}{c}\text { extr. } \\
\text { in } \mathrm{HCl}\end{array}$ & $\begin{array}{c}\text { extr. in } \\
\mathrm{Ca}\left(\mathrm{NO}_{3}\right)_{2}\end{array}$ & total & $\begin{array}{c}\text { extr. } \\
\text { in } \mathrm{HCl}\end{array}$ & $\begin{array}{c}\text { extr. in } \\
\mathrm{Ca}(\mathrm{NO} 3)_{2}\end{array}$ & total & $\begin{array}{c}\text { extr. } \\
\text { in } \mathrm{HCl}\end{array}$ & $\begin{array}{c}\text { extr. in } \\
\mathrm{Ca}(\mathrm{NO} 3)_{2}\end{array}$ & total & $\begin{array}{c}\text { extr. } \\
\text { in } \mathrm{HCl}\end{array}$ & $\begin{array}{c}\text { extr. in } \\
\mathrm{Ca}(\mathrm{NO} 3)_{2}\end{array}$ \\
\hline $\begin{array}{l}\text { zinc } \\
\text { waste }\end{array}$ & 10409.1 & 4223.0 & 13.95 & 1666.7 & 1093.7 & 0.3 & 23.7 & 19.3 & 0.43 & 31.1 & 26.2 & 0.08 \\
\hline stand A & 7.1 & 6.1 & 0.35 & 22.6 & 19.7 & 0.1 & 0.94 & 0.92 & 0.03 & 7.1 & 6.1 & 0.065 \\
\hline stand B & 11.5 & 6.9 & 8.2 & 30.3 & 13.8 & 0.0 & 1.84 & 0.59 & 0.36 & 11.5 & 6.9 & 0.225 \\
\hline
\end{tabular}

TABLE 2. Soil chemical characteristics of zinc wastes, stand A and B.

\begin{tabular}{|l|c|c|c|c|c|c|c|}
\hline & type of soil & $\begin{array}{c}\text { organic matter } \\
\text { content [\%] }\end{array}$ & $\mathrm{N}[\%]$ & $\begin{array}{c}\mathrm{P}_{2} \mathrm{O}_{5} \\
{\left[\mathrm{mg} \mathrm{kg}^{-1}\right]}\end{array}$ & $\begin{array}{c}\mathrm{K}_{2} \mathrm{O} \\
{\left[\mathrm{mg} \mathrm{kg}^{-1}\right]}\end{array}$ & $\begin{array}{c}\mathrm{CaO} \\
{\left[\mathrm{mg} \mathrm{kg}^{-1}\right]}\end{array}$ & $\mathrm{pH}$ in $\mathrm{H}_{2} \mathrm{O}$ \\
\hline zinc waste & sandy soil & 1.12 & 0.044 & 74 & 69 & 2509 & 7.4 \\
\hline stand A & sandy soil & 4.99 & 0.301 & 134 & 137 & 4960 & 7.2 \\
\hline stand B & silty soil & 3.50 & 0.151 & 45 & 135 & 1053 & 4.6 \\
\hline
\end{tabular}


The procedure for the rhodizoniate test modified after Garty and Theiss (1990) was as follows: $50 \mathrm{mg}$ of the rhodizonian was dissolved in $25 \mathrm{ml}$ of a buffer ( $\mathrm{pH} 2.8$ ) containing $1.5 \mathrm{~g}$ of tartaric acid and $1.9 \mathrm{~g}$ of sodium bitartrate in $100 \mathrm{ml}$ of distilled water. These roots, washed in water, often sectioned longitudinally, were soaked in this solution for 5 hours, transfered into a buffer as described above but without rhodizoniate and observed under a stereomicroscope. Roots were selected according to intensity of reaction and $1 \mathrm{~cm}$-long root pieces were placed in lactic acid on a slide, covered and observed under a light microscope.

In addition, roots selected under the stereomicroscope according to their reaction to rhodizoniate were stained with cotton blue and analysed according to Trouvelot et al. (1986).

SEM Jeol JSM 5410 with an energy dispersion system (EDS) (NORAN system) was used for analysis of spores (crushed and dried) and roots after standard preparation (fixed for $1 \mathrm{~h}$ in $3 \%$ glutaraldehyde in $0.2 \mathrm{M}$ Hepes buffer, dehydrated, critical-point dried and coated with carbon) and longitudinal sectioning. The samples were fixed on carbon stubs and covered with carbon prior to analysis. At least ten analyses were carried out for each kind of plant and fungal structure described.

TEM 902 Zeiss observations were carried out on samples prepared as described by Turnau et al (1993).

\section{RESULTS}

\section{Heavy metal content of $\boldsymbol{E}$. cyparissias}

Despite a high heavy-metal content of zinc wastes, the concentration of potentially toxic elements in E. cyparisssias shoots was rather low (Fig. 1). In comparison to the heavy metal content in shoots of specimens collected from stand A and $\mathrm{B}$ (natural stands) only $\mathrm{Pb}$ concentration had increased significantly. On the contrary, in shoots collected from stand $\mathrm{B}$, where the $\mathrm{pH}$ value was much lower, $\mathrm{Cu}, \mathrm{Zn}$ and $\mathrm{Cd}$ values were even higher than in shoots from the zinc wastes. No significant differences were found in the As content of all samples analyzed. Though there were important differences in the P, $\mathrm{N}$ and Ca contents of the analyzed stands no significant differences were found among these element contents in shoots. The heavy metal concentrations in roots from zinc wastes were $75 \mathrm{ug} \mathrm{g}^{-1}$ for $\mathrm{Zn}, 20 \mathrm{ug} \mathrm{g}^{-1}$ for $\mathrm{Pb}, 2 \mathrm{ug} \mathrm{g}^{-1}$ for $\mathrm{Cd}, 6.5 \mathrm{ug} \mathrm{g}^{-1}$ for $\mathrm{Cu}$, in roots from stand $\mathrm{A}: 67 \mathrm{ug} \mathrm{g}^{-1}$ for $\mathrm{Zn}, 12 \mathrm{ug} \mathrm{g}^{-1}$ for $\mathrm{Pb}, 2 \mathrm{ug} \mathrm{g}^{-1}$ for $\mathrm{Cd}$ and $4,5 \mathrm{ug} \mathrm{g}^{-1}$ for $\mathrm{Cu}$ and from stand B: $50 \mathrm{ug} \mathrm{g}^{-1}$ for $\mathrm{Zn}, 3 \mathrm{ug} \mathrm{g}^{-1}$ for $\mathrm{Pb}, 0.1 \mathrm{ug} \mathrm{g}^{-1}$ for $\mathrm{Cd}$ and $2.5 \mathrm{ug} \mathrm{g}^{-1}$ for $\mathrm{Cu}$. Roots from area of low $\mathrm{pH}$ contained 2 to 3 times less of $\mathrm{Pb}$ and $\mathrm{Cu}, 10$ times less $\mathrm{Cd}$ and similar level of $\mathrm{Zn}$ than in roots from zinc wastes. On the contrary, $\mathrm{Ca}$ level in roots from stand $\mathrm{B}$ was nearly four times lower ( $7150 \mathrm{~g} \mathrm{~g}^{-1}$ ). The rhizomes from zinc wastes accumulated higher heavy metal concentrations up to $110 \mathrm{~g} \mathrm{~g}^{-1}$ of $\mathrm{Pb}$ and $300 \mathrm{~g} \mathrm{~g}^{-1}$ of $\mathrm{Cu}$.

\section{Mycorrhizal status of $\boldsymbol{E}$. cyparissias from zinc wastes and comparative areas}

Mycorrhizal colonization seemed to be correlated more to the $\mathrm{pH}$ level than to the heavy-metal content (Fig. 2). No significant differences in F, M and A \% were found between roots from zinc wastes and stand $\mathrm{A}$, both characterized by a $\mathrm{pH}$ value of around 7. At the same time, mean values of $F, M$ and $\mathrm{A}$ estimated in roots from stand $\mathrm{B}(\mathrm{pH} 4.5)$ were at least

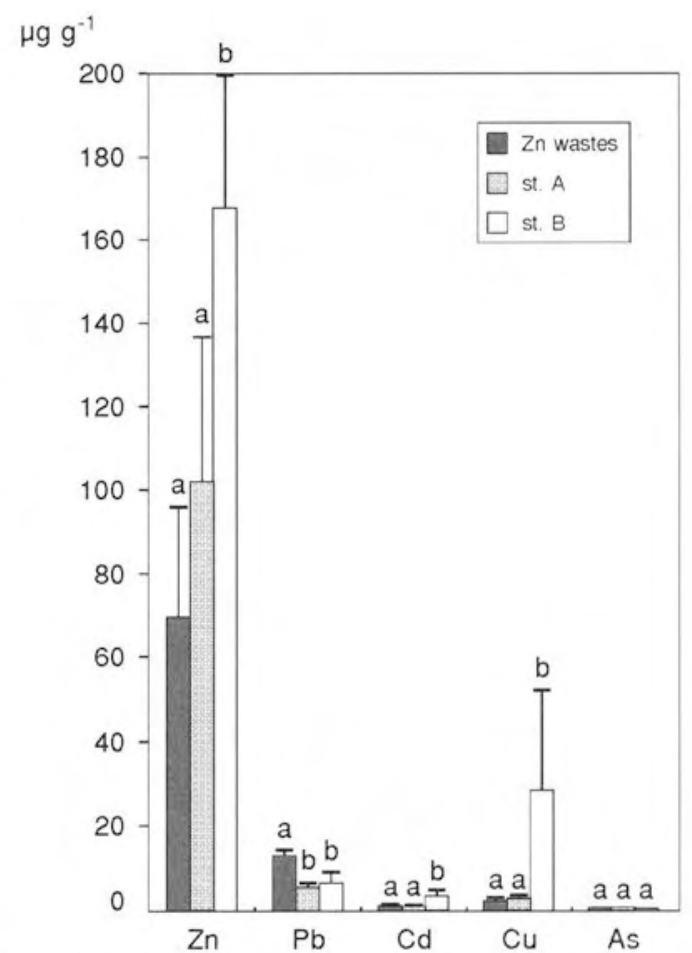

Fig. 1. Metal concentrations $\left(\mu \mathrm{g} \mathrm{g}^{-1} \mathrm{~d}\right.$. wt) in Euphorbia cyparissias shoots collected from zinc wastes, stand A (Kostrze) and stand B (Wierzbanowka Valley). Means $\pm \operatorname{SE}(n=5)$. Different letters above columns indicate a significant difference at $p<0.05$.

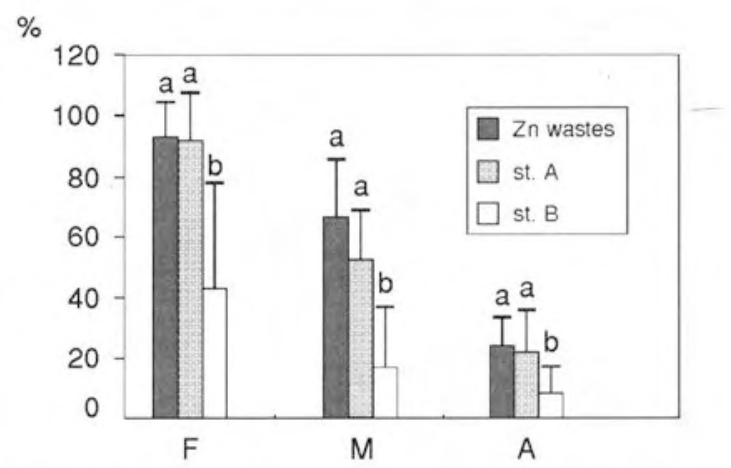

Fig. 2. Arbuscular mycorrhizal colonization of Euphorbia cyparissias collected from zinc wastes, stand A (Kostrze) and stand B (Wierzbanowka Valley). Frequency of infected root segments (F\%), total mycorrhizal intensity $(\mathrm{M} \%)$ and relative arbuscular richness in whole root system $(A \%)$. Means \pm SE $(n=5)$. Different letters above columns indicate a significant difference at $\mathrm{p}<0.05$.

two times lower. In the latter case, a high frequency of parasitic fungi and nematodes (eggs) within the roots was observed. On the basis of the above described data, stand A was selected as a control site for further work on the influence of pollution on mycorrhizal colonization. At the beginning of the vegetation season, parallelly growing hyphae (Fig. 3) without arbuscule formation or with so-called "aborted arbuscules" were abundant within the roots of E. cyparissias from zinc wastes (Fig. 4). Most of these roots, while observed with TEM, appeared to be dead though the hyphae were clearly vital (not shown). Later in the vegetation season this phenomenon was not observed. Abundant arbuscules were locally present (Fig. 5), sometimes with poorly-developed, fine branching or sometimes with a net- rather than a tree-like structure. The analysis of root material from unpolluted stand $\mathrm{A}$ has 


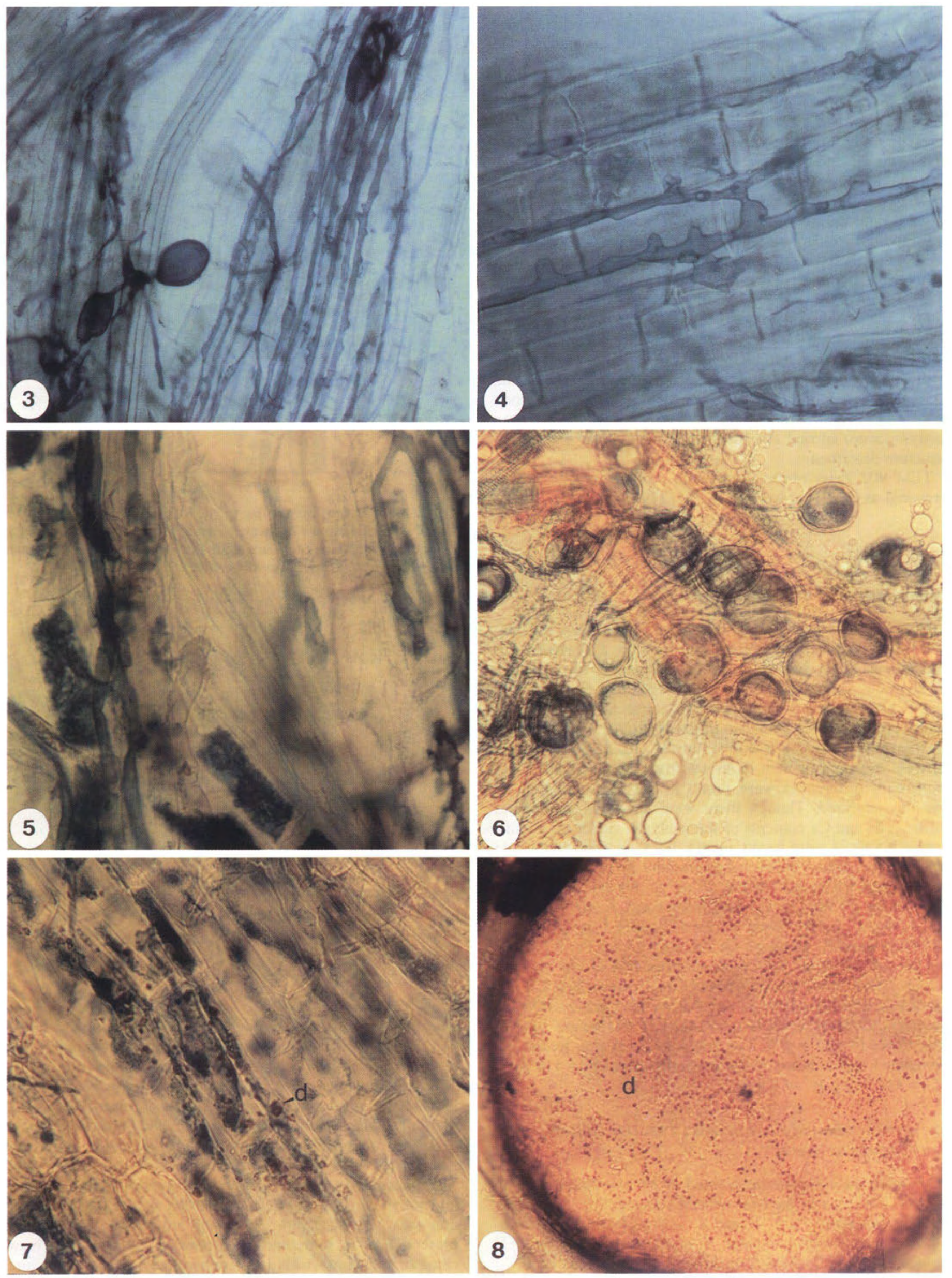



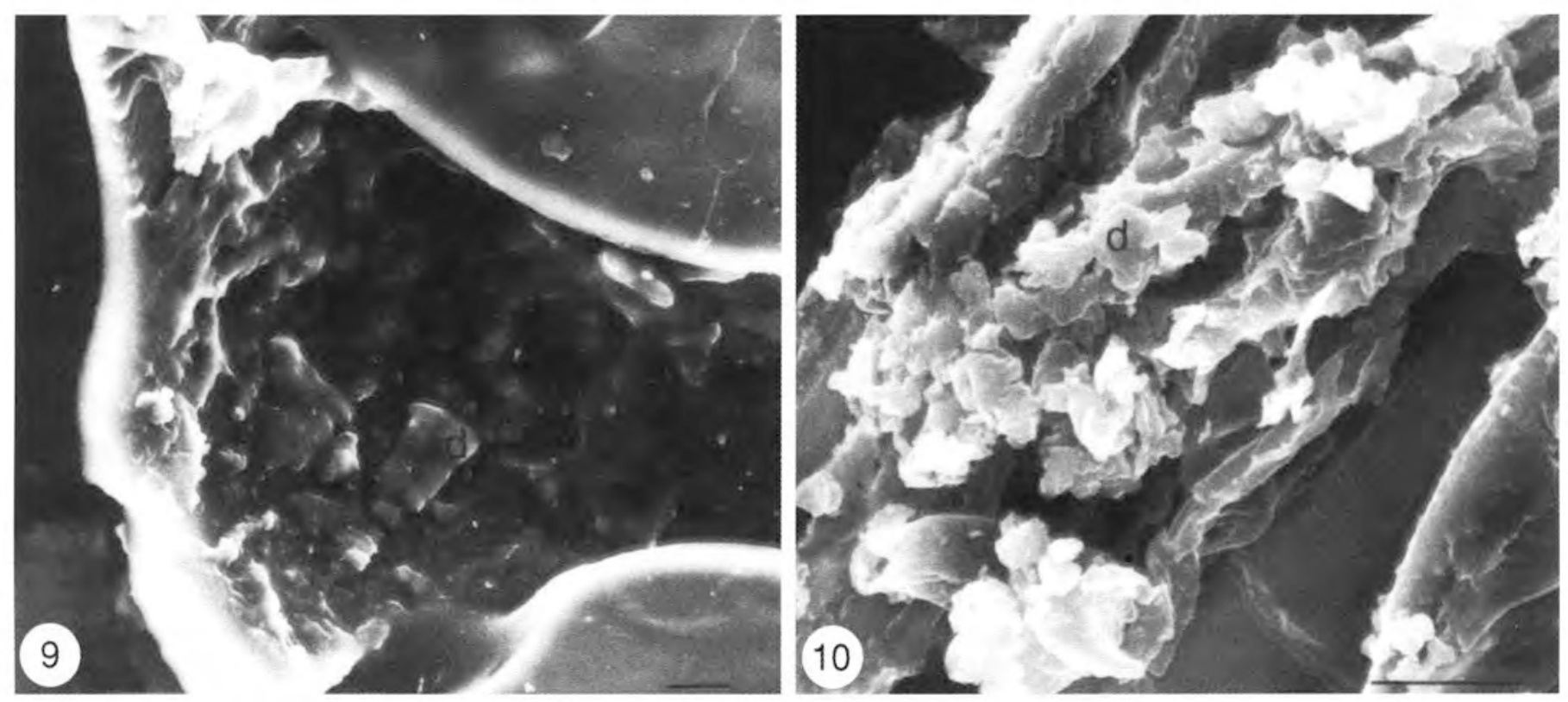

Fig. 9. SEM micrographs of the inner layer of a spore wall with small depositions (d) characterized by a high content of potentially toxic elements; bar $=10 \mu \mathrm{m}$.

Fig. 10. SEM micrograph of a longitudinal section through a Euphorbia cyparissias root showing abundant depositions (d) around the hyphae; heavy metals have been detected in these depositions; bar $=10 \mu \mathrm{m}$.

shown typical arbuscules, with well-developed, fine branching, no cases of mycelium growth completely devoid of arbuscule formation, as described from the zinc wastes.

\section{Heavy metal localization according to the rhodizoniate test}

The rhodizoniate staining within E. cyparissias roots from zinc wastes is much higher than in roots from control sites. The change of colour was visible in the cell walls of the epidermis, including the walls of root hairs. In up to $80 \%$ of roots, the intraradical mycelium was also stained. The stained intracellular mycelium was usually accompanied by distinctly stained depositions (crystaloids) localized within the plant cells (Fig. 7, 10). They were especially common around stained mycelium, often appearing as crystaline crust over fungal hyphae. In the remaining $20 \%$ of the roots no reaction of the mycelium to rhodizoniate was observed despite of similar abundance of mycorrhiza (M\%). The depositions were only occasionally observed and uniformly distributed. Similar depositions were localized within lactifers, within root hairs and to a lower extent within cortical and epidermal cells devoid of mycelium. The roots were divided into two classes according to intensity of rhodizoniate staining. After clearing them with $\mathrm{KOH}$ and staining with cotton blue, F, M and $\mathrm{A} \%$ were estimated. This method revealed no significant differences in $\mathrm{F}$ and $\mathrm{M}$ but showed clearly that in roots where the rhodizoniate staining was poor, arbuscule development is more abundant than in stained ones (Fig. 11).
Heavy metal localization according to the energy dispersion system connected to SEM

Roots stained with rhodizoniate or unstained (for comparison) from the zinc waste were observed with SEM equiped with an EDS system (Figs 12, 13, Table 3). In the epidermis cell walls a maximum $5 \%$ of heavy metals $(\mathrm{Cu}-$ up to $1.4 \%, \mathrm{~Pb}$ $-1.5 \%$ and $\mathrm{Zn}-1.5 \%$ dry wt) was found. As in all biological samples, $\mathrm{C}$ and $\mathrm{O}$ were the main components of the cell walls. In addition $\mathrm{Ca}(3.8-5.0 \% \mathrm{wt}), \mathrm{S}(0.5-0.6 \%)$ and $\mathrm{P}(0.1-$ $0.5 \%$ ) were found. Much lower levels of heavy metals were found in the cell walls of root hairs (up to $2 \%$ ).

Despite large differences in the heavy metal content of fungal cell walls, in mycelium in which heavy metals were found, the levels of $\mathrm{Cu}$ and $\mathrm{Pb}$ were significantly lower than in epidermal cell walls, while the $\mathrm{Zn}$ level was similar. On the surface of the intraradical mycelium, amorphic or crystaloid depositions were distinguished. In the amorphic ones a high level of $\mathrm{S}, \mathrm{P}$ and $\mathrm{As}$ was found, while in crystaloids more $\mathrm{Ca}$ and $\mathrm{Fe}$ and slightly less As were detected. In both of them $\mathrm{Si}, \mathrm{Pb}, \mathrm{Cu}$ and $\mathrm{Zn}$ were more or less on a similar level (Tab. 3, Fig. 13). The depositions were characterized by a significantly higher level of $\mathrm{Zn}, \mathrm{Fe}$ and $\mathrm{Al}$ than the epidermal cell wall, the fungal mycelium wall or any other structures analyzed. They were also very rich in $\mathrm{Ca}$ and $\mathrm{Si}$.

Analysis of unstained roots has shown the presence of heavy metal only in outer cell wall of epidermis and in root hairs. The heavy metals were under detection limit within walls of fungal hyphae.

Fig. 3-4. Mycorrhizal mycelium growing parallelly within Euphorbia cyparissias roots, forming only "aborted arbuscules" - a common case at the beginning of the vegetation period on zinc wastes; magn.: $3-160 x, 4-400 x$.

Fig. 5. Arbuscules within a E. cyparissias cortical cell from zinc wastes; magn. 400x

Fig. 6. Spores of Glomus sp. formed intraradically; orange staining of cortical walls results from a positive reaction to the rhodizoniate test, which is weak or negative in spore walls; magn. 160x.

Fig. 7. Depositions (d) formed within plant cells close to the fungal hyphae, giving a positive reaction to the rhodizoniate test; magn. 400x.

Fig. 8. Depositions (d) stained by rhodizoniate localized within spores of Glomus sp. isolated from nearby E. cyparisias roots in zinc wastes; magn. 400x. 
$\%$

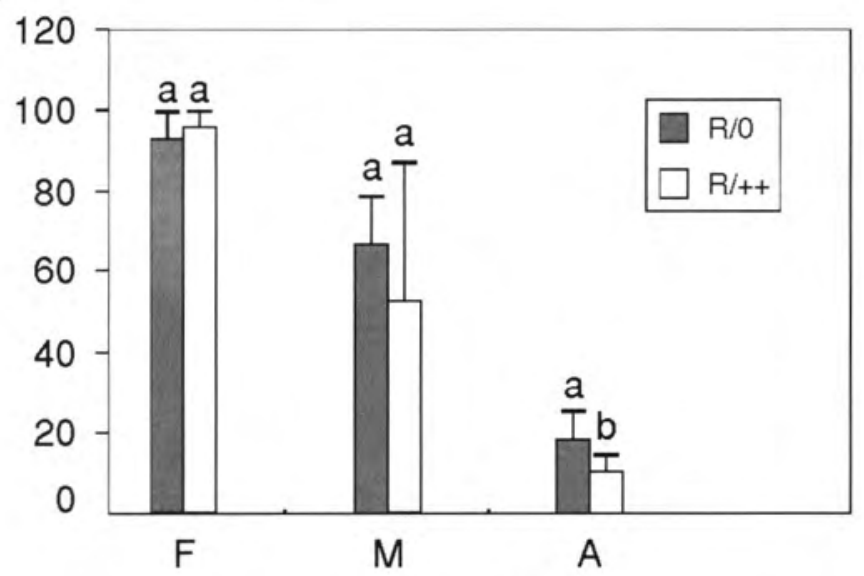

Fig. 11. Comparison of arbuscular mycorrhizal infection in Euphorbia cyparissias roots, collected from zinc wastes, showing a positive $(\mathrm{R} /++)$ or negative $(\mathrm{R} / 0)$ reaction to rhodizoniate test. The frequency of infected root segments (F\%), total mycorrhizal intensity ( $\mathrm{M} \%)$, and relative arbuscular richness in the whole root system analyzed $(A \%)$ are given. Means \pm SE $(n=25)$. Different letters above columns indicate a significant difference at $\mathrm{p}<0.05$.

\section{Heavy metal localization within glomalean spores}

Further differences between the zinc wastes and control sites concerned the presence of a high number of intraradical spores within the roots from industrial wastes (Fig. 6). Six spore morphotypes were isolated from the zinc waste substratum surrounding the roots of E. cyparissias. They were much less frequent than spores within roots. In some cases, extraradical spores were found within dead spores of a different morphotype or within unidentified plant debris.

The rhodizoniate test used for spores selected from zinc wastes revealed differences between morphotypes. Intraradical spores were usually devoid of heavy metals. Among the spores formed outside roots, two groups of morphotypes were distinguished. The first one (three morphotypes) was characterized by uniform, positive rhodizoniate staining of the spore wall. The spore walls of the second group (two morphotypes) gave no reaction to rhodizoniate and zero or low levels of heavy metals were found using a EDS analyzer. Instead, small depositions containing heavy metals were found on the inner surface of the spore wall (Figs 8-9). Pb and $\mathrm{Cu}$ had similar levels there as in plant crystaloids and in fungal cell walls, and the $\mathrm{Zn}$ content was only a bit lower than in plant crystaloids. $\mathrm{Ca}, \mathrm{Si}$ and $\mathrm{Al}$ were also found in the spore depositions.

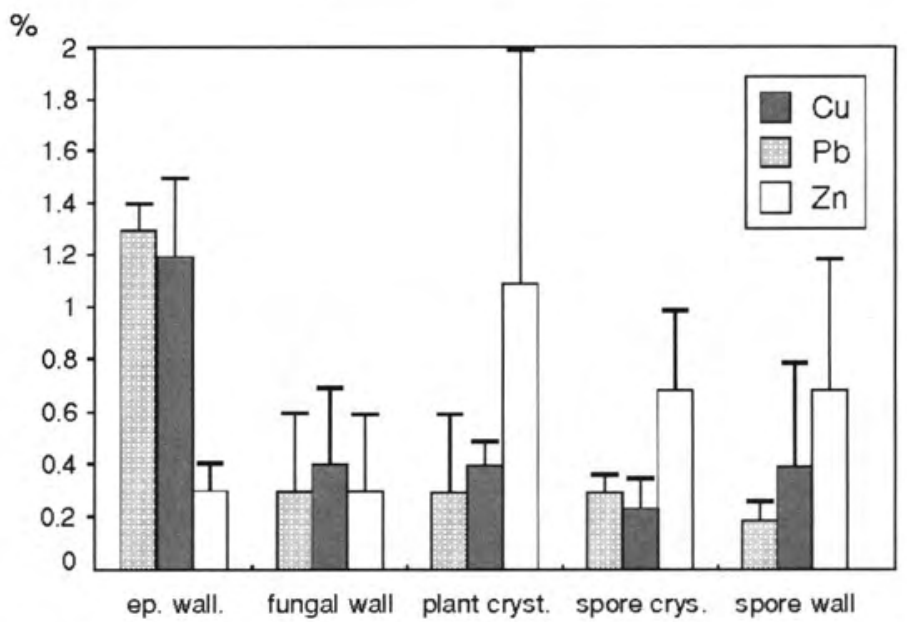

Fig. 12. Copper, lead and zinc content of epidermal cell wall (ep. wall), surface layer of the intraradical mycelium, plant crystaloids deposited around the mycelium (plant cryst.) spore depositions (spore cryst.) and spore walls as estimated by EDS analysis; mean values in \% dry weight $\pm \operatorname{SE}(n=10)$.

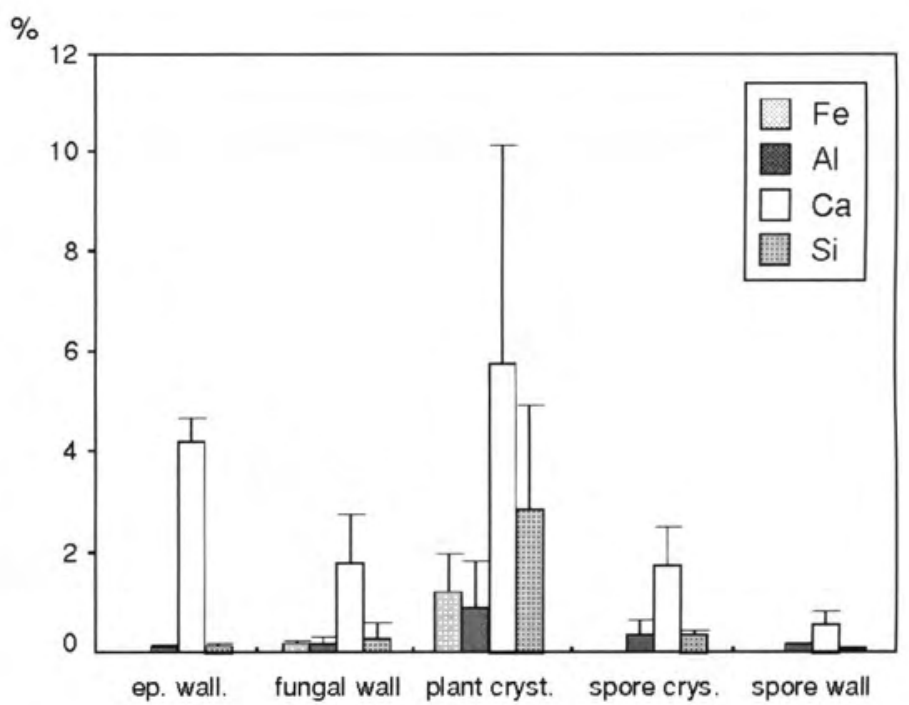

Fig. 13. Ferrous, aluminium, copper and silicon content of epidermal cell wall (ep. wall), surface layer of the intraradical mycelium, plant crystaloids deposited around the mycelium (plant cryst.) spore depositions (spore cryst.) and spore walls as estimated by EDS analysis; mean values in $\%$ dry weight $\pm \mathrm{SE}(\mathrm{n}=10)$.

TABLE 3. Element content in the epidermal cell wall (ep. wall), surface layer of the intraradical mycelium, plant crystaloids deposited around mycelium (plant cryst.) spore depositions (spore cryst.) and spore walls as estimated by EDS analysis; mean values in \% dry weight ( \pm SD; $\mathrm{n}=10$ ) different letters beside indicate a significant difference at $\mathrm{p}<0.05$.

\begin{tabular}{|l|c|c|c|c|c|c|c|c|}
\hline & $\mathrm{Cu}$ & $\mathrm{Pb}$ & $\mathrm{Zn}$ & $\mathrm{Ni}$ & $\mathrm{Fe}$ & $\mathrm{Al}$ & $\mathrm{Ca}$ & $\mathrm{Si}$ \\
\hline ep. wall & $1.3 \mathrm{a}$ & $1.2 \mathrm{a}$ & $0.3 \mathrm{a}$ & $0 \mathrm{a}$ & $0 \mathrm{a}$ & $0.1 \mathrm{a}$ & $4.2 \mathrm{a}$ & $0.1 \mathrm{a}$ \\
\hline fungal wall & $0.3 \mathrm{~b}$ & $0.4 \mathrm{~b}$ & $0.3 \mathrm{a}$ & $0 \mathrm{a}$ & $0.2 \mathrm{~b}$ & $0.2 \mathrm{a}$ & $1.8 \mathrm{~b}$ & $0.3 \mathrm{a}$ \\
\hline plant cryst. & $0.3 \mathrm{~b}$ & $0.4 \mathrm{~b}$ & $1.1 \mathrm{~b}$ & $0 \mathrm{a}$ & $1.2 \mathrm{c}$ & $0.9 \mathrm{~b}$ & $5.8 \mathrm{a}$ & $2.9 \mathrm{~b}$ \\
\hline spore cryst. & $0.3 \mathrm{~b}$ & $0.2 \mathrm{~b}$ & $0.7 \mathrm{a}$ & $0.2 \mathrm{~b}$ & $0 \mathrm{a}$ & $0.4 \mathrm{a}$ & $1.8 \mathrm{~b}$ & $0.4 \mathrm{a}$ \\
\hline spore wall & $0.2 \mathrm{~b}$ & $0.4 \mathrm{~b}$ & $0.6 \mathrm{a}$ & $0 \mathrm{a}$ & $0 \mathrm{a}$ & $0.1 \mathrm{a}$ & $0.6 \mathrm{c}$ & $0.1 \mathrm{a}$ \\
\hline
\end{tabular}


The depositions or staining of cell walls were never observed within spores collected from control plots.

\section{DISCUSSION}

E. cyparissias is a typical stress-tolerant plant, long-lived, spreading extensively by vegetative propagation and having a low maximum growth rate. Adapted for long-term survival, but with a poorly-developed root system, it apparently benefits from AM, by which it maximises the capture of water and mineral nutrients (Grime 1977). Mycorrhiza development however may lead to an increase or decrease in heavy metal uptake by the plant (see review by Leyval et al 1997). Metal bioavailability is a function not of only their total concentration, but also of such factors as $\mathrm{pH}$, organic matter and biological factors (Berthelin et al. 1995). Despite the higher heavy-metal content on the zinc wastes $\mathrm{Zn}$ and $\mathrm{Cd}$ uptake by plant was lower than in stand B where the heavy metal concentration was very low. This can be attributed to the high availability of the metals, as shown by $\mathrm{Ca}\left(\mathrm{NO}_{3}\right)_{2}$ extraction, in stand $\mathrm{B}$ due to lower $\mathrm{pH}$ and $\mathrm{CaO}$ content. In comparison to zinc wastes soil of stand $\mathrm{B}$ was characterized by higher $\mathrm{Cu}$ availability and nearly equal content of $\mathrm{Cd}$. High pollution of this stand could be explained by the influence of aluminium smelter located nearby, operating for thirty years and emiting fluorine compounds into the air. The activity of this smelter resulted in strong decrease of soil $\mathrm{pH}$ and $\mathrm{Ca}$ content (Table 1). In such cases not only the toxicity of heavy metals is increased due to low $\mathrm{pH}$ but also the lack of $\mathrm{Ca}$ which is the antagonist towards heavy metals as $\mathrm{Cd}, \mathrm{Zn}, \mathrm{Pb}$ and $\mathrm{Cu}$ could be responsible for the situation (Kabata-Pendias and Pendias 1993).

In the zinc waste, although the total heavy metal concentrations were very high the availability was very low. However it was still higher than in stand $\mathrm{A}$ and it was of the same order of magnitude as in polluted soils studied by Weissenhorn et al. $(1993,1995 \mathrm{c})$. When comparing the heavy-metal content of plants and mycorrhizal development one must also remember that particularly at differing $\mathrm{pH}$ values and organic matter content of the substratum, not only the bioavailability of metals differ but the mycorrhizal colonization or functioning could also be altered. At minimum arbuscule richness if not vitality should be evaluated in the samples compared. In case of E. cyparissias growing on the zinc wastes, arbuscule modifications were observed, sometimes resulting in so-called "aborted" arbuscules or in weakly branched arbuscules. Preliminary observations on vitality of E. cyparissias roots suggest that these kind of structures are mainly formed within dead roots (unpublished results). Weak development of arbuscules and a slight decrease in arbuscule richness which was found in E. cyparissias exhibiting positively rhodizoniate stained mycelium, might be a sign of mycelium disfunction or a result of plant influence (inhibition) on the fungus, but may also result from differences between species or strains regarding their ability to form arbuscules.

Differences in heavy metal content (shown by rhodizoniate test and confirmed by EDS method) between mycorrhizal mycelia of E. cyparissias roots were probably due to different ability of fungal strains or species to sequester heavy metals within cell walls. Around intracellular mycelium characterized by the presence of heavy metals in hyphal walls, within the plant cytoplasm, depositions containing high levels of potentially toxic elements were found. Similar deposition were found within latices. The latex of some members of Euphorbiaceae has previously been shown (Baier et al. 1992; Baier and Heinrich 1993) to contain $\mathrm{Ca}, \mathrm{K}, \mathrm{Mg}, \mathrm{Na}$ and also is rich in several organic acids which could potentially bind heavy metals (Murphy and Levy 1983; Sieghardt 1985; Macaskie and Dean 1990). As the production of latex is now considered a detoxification mechanism (Baier and Heinrich 1993) it was not surprising that in E. cyparissias from zinc wastes heavy metals were also found in the latex. The depositions within cortical cells and within latex could function as a filter for elements transfered from the wastes and might play similar role as a barrier in a form of epidermis walls chelating heavy metals (Wierzbicka 1987b).

The ability of a plant symbiont to detoxify heavy metals transfered via the fungus has been shown in the case of Pteridium aqilinum (Turnau et al. 1993). This is an extremely resistant species which was one of the few ones able to colonize forest experimental plots treated with high level of cadmium and zinc dust in Poland (Turnau et al. 1993). When the mycorrhizal root sections were observed in TEM equiped with EELS/ESI the heavy-metal content was higher within the fungal cytoplasm than in the plant cytoplasm.

Also mycorrhizal fungi of $E$. cyparissias from zinc wastes have shown several strategies against heavy metals. The spores were more abundant within the roots, and because of this heavy metal access was diminished. The mycelium germinating from such spores was often growing intraradically towards freshly formed roots, using dead roots as tunnels of much lower toxicity. This phenomenon was most clearly visible at the beginning of the vegetation period. In spores formed in the soil, the cell wall or the depositions on the inner layer of the wall probably served as deposition sites for potentially toxic elements.

The accuracy of the rhodizoniate test was confirmed in the present work by the EDS analyzer. In the future, the use of this test could lower the costs of SEM and EDS system application, as it is a good method for selecting material from polluted sites. The comparative investigation of rhodizoniate treated and untreated material did not show any significant differences in the localization of elements. A comparison between chemically-fixed and dried material has shown that during fixation the level of some elements either decreases or increases. However, there was no significant differences in case of heavy metals. Though drying the samples is sufficient for analyzing cell walls of the epidermis, mycelium growing on the root surface or outer spore walls, visualization and recognition of plant or fungal crystaloids was much easier in fixed material.

\section{ACKNOWLEDGEMENTS}

Special thanks are due to Dr Corinne Leyval (Centre de Pedologie Biologique, Nancy, France) and to Professor Paola Bonfante (Universita di Torino, Italy) for advice and critical reading of the manuscript. The author also wishes to thank Ms. Ewa Slusarczyk for the help in collecting material and slide preparation, Ms. Jadwiga Faber for excellent technical assistance with EDS analysis carried out at the Department of Zoology of Jagiellonian University (Electron Microscopy Unit) and to Dr Barbara Godzik (Polish Academy of Sciences, Krakow, Poland) for the help in estimation of heavy metal availability. The SEM and EDS equipment is the donation of the Foundation for Polish Science (SUBIN 94). The research was supported by the Committee of Scientific Research in Poland, grant no. PB 0860/P04/96/11. 


\section{LITERATURE CITED}

BAIER W. R., HEINRICH G., 1993. Gas-liquid chromatographic analyses of the water-soluble compounds of plant latices. Phyton 33 (1): 77-85.

BAIER W. R., KOSMUS W., HEINRICH G., 1992. Sodium, magnesium, potassium and calcium in plant latices. Phyton 31: 227232

BERTHELIN J., MUNIER-LAMY C., LEYVAL C., 1995. Effect of microorganisms on mobility of heavy metals in soils. In: Huang PM, Berthelin J, Bollag JM, McGill WB, Page AL (eds) Environmental Impacts of Soil Component Interactions: Vol. 2 - Metals, Other Inorganics and Microbial Activities. II. Lewis Publishers, Boca Raton, pp. 3-17.

CHAO C. C.. WANG Y. P., 1991. Effects of heavy metals on vesicular-arbuscular mycorrhizae and nitrogen fixation of soybean in major soil groups of Taiwan. J Chin Agric Chem 29: 290-300.

EL KHERBAWY M., ANGLE J. S., HEGGO A., CHANEY R. L., 1989. Soil pH, rhizobia and vesicular-arbuscular mycorrhizae inoculation effects on growth and heavy metal uptake of alfalfa (Medicago sativa L.). Biol Fertil Soils 8: 61-65.

FEIGL F., 1954. Spot Tests, V. 1. Inorganic Applications. Elsevier Publ. Co. Amsterdam.

GARTY J., THEISS H. B., 1990. The localization of lead in the lichen Ramalina duriaei (De Not.) Bagl. Bot. Acta 103: 311-314.

GILDON A., TINKER P. B., 1983. Interactions of vesicular-arbuscular mycorrhizal infection and heavy metals in plants. 1. The effects of heavy metals on the development of vesicular-arbuscular mycorrhizas. New Phytol 95: 247-261.

GLATEER F. A. B., HERNANDEZ L., 1972. Lead detection in living plant tissue using a new histochemical method. J Air Pollut Control Assoc 22: 463-467.

GRAHAM J. H., TIMMER L. W., FARDELMANN D., 1986. Toxicity of fungicidal copper in soil to Citrus seedlings and vesiculararbuscular mycorrhizal fungi. Phytopathol 76: 66-70.

GRODZIŃSKA K., 1978. Mosses as bioindicators of heavy metal pollution in Polish national parks. Water, Air and Soil Pollution 9: 83-97.

GRIME J. P., 1977. Evidence for the existence of three primary strategies in plants and its relevance to ecological and evolutionary theory. An Nat 111: 1169-1194.

KABATA-PENDIAS A., PENDIAS H., 1993. Biogeochemia pierwiastków śladowych. PWN, Warszawa.

KILLHAM K., FIRESTONE M. K., 1983. Vesicular arbuscular mycorrhizal mediation of grass response to acidic and heavy metal depositions. Plant Soil 72: 39-48.

KOOMEN I., MCGRATH S. P., GILLER K., 1990. Mycorrhizal infection of clover is delayed in soils contaminated with heavy metals from past sewage sludge applications. Soil Biol Biochem 22: 871873.

LEKAN S., PIOTROWSKA M., 1988. Ocena stanu środowiska rolniczego wokół osadników odpadów poflotacyjnych i Zakładu Górniczego "Szyb Włodzimierz", Raport no. 413-34/87.

LEYVAL C., BERTHELIN J., SCHONTZ D., WEISSENHORN I., MOREL J. L., 1991. Influence of endomycorrhizas on maize uptake of $\mathrm{Pb}, \mathrm{Cu}$ and $\mathrm{Cd}$ applied as mineral salts or sewage sludge. In: J. G. Farmer (ed.), Heavy metals in the environment. CEP Consultants, Ltd., Edinburgh, pp. 204-207.

LEYVAL C., TURNAU K., HASELWANDTER K., 1997. Effect of heavy metal pollution on mycorrhizal colonization and function: physiological, ecological and applied aspects. Mycorrhiza (in press).

MACASKIE L. E., DEAN A. C. R., 1990. Metal-Sequestering bichemicals. In: B Volesky (ed.), Biosoption of heavy metals. CRC Press, Boca Ratton, pp. 199-248.

MCGEE P. A., 1987. Alteration of growth of Solanum opacum and Plantago drummondii and inhibition of regrowth of hyphae of vesicular-arbuscular fungi from dried pieces by manganese. Plant Soil 101: 227-233.

MURPHY R. J., LEVY J. F., 1983. Production of copper oxalate by some copper tolerant fungi. Trans Br Mycol Soc 81: 165-168.

NOWOSIELSKI O., 1968. Metody oznaczania potrzeb nawożenia. PWRiL, Warszawa, pp. 1-668.

PHILLIPS J., HAYMAN D. S., 1970. Improved procedures for clearing roots and staining parasitic and vesicular-arbuscular mycorrhizal fungi for rapid assessment of infection. Trans Br. Mycol. Soc. 55: 158-161

SCHÜEPP H., DEHN B., STICHER H., 1987. Interaktionen zwischen VA-mykorrhizen und schwermetallbelastungen. Angew Bot 61: 85-95.

SIEGHARDT H., 1985. Zur Frage der Besiedelung schwermetallhaltiger Abraumhalden in Bleiberg/Karnten. Teil I: Silene vulgaris ssp. galerosa (Jord.) Marsden-Jones \& Turill. Carinthia II 175: $27-45$.

SILVERBERG B. A., 1975. Ultrastructural localization of lead in Stigeoclonium tenue (Chlorophyceae, Ulotrichales) as demontrated by cytochemical and X-ray microanalysis. Phycologia 14: 265-274

THEISS H. B., 1987. Histochemischer Nachweis von Blei in Cladophora. Mikrokosmos 76: 108-109.

TOMMERUP I. C., 1992. Methods for the study of the population biology of vesicular-arbuscular mycorrhizal fungi. In: JR Norris, DJ Read \& AK Varma (eds) Methods in Microbiology. Vol. 24. Techniques for the study of mycorrhiza. Academic Press, London, pp. 23-51.

TROUVELOT A., KOUGH J. L., GIANINAZZI-PEARSON V., 1986. Mesure du taux de mycorhization VA dun systeme radiculaire. Recherche de methodes destimation ayant une signification fonctionnelle. In: V. Gianinazzi-Pearson \& S. Gianinazzi (eds) Physiological and Genetical Aspects of Mycorrhizae. INRA, Paris, pp. 217-221.

TURNAU K., KOTTKE I., OBERWINKLER F., 1993. Element localization in mycorrhizal roots of Pteridium aquilinum (L.) Kuhn collected from experimental plots treated with cadmium dust. New Phytol 123: 313-324.

TURNAU K., MISZALSKI Z., TROUVELOT A., BONFANTE P., GIANINAZZI S., 1996. Oxalis acetosella as a monitoring plant on highly polluted soils. In: C. Azcon-Aguilar, J. M. Barea (eds) Mycorrhizas in integrated systems from genes to plant development. Proceedings of the fourth European Symposium on Mycorrhizas., pp. 483-486.

WEISSENHORN I., LEYVAL C., BERTHELIN J., 1993. Cd-tolerant arbuscular mycorrhizal (AM) fungi from heavy-metal polluted soils. Plant Soil 157: 247-256.

WEISSENHORN I., LEYVAL C., 1995. Root colonization of maize by a Cd-sensitive and a Cd-tolerant Glomus mossae and cadmium uptake in sand culture. Plant Soil 175: 233-238.

WEISSENHORN I., LEYVAL C., BELGY G., BERTHELIN J., 1995a. Arbuscular mycorrhizal contribution to heavy metal uptake by maize (Zea mays L.) in pot culture with contaminated soil. Mycorrhiza 5: 245-251.

WEISSENHORN I., LEYVAL C., BERTHELIN J., 1995b. Bioavailability of heavy metals and abundance of arbuscular mycorrhiza in a soil polluted by atmospheric deposition from a smelter. Biol. Fert Soils 19: 22-28.

WEISSENHORN I., MENCH M., LEYVAL C., 1995c. Bioavailability of heavy metals and arbuscular mycorrhiza in a sewage-sludge-amended sandy soil. Soil Biol. Biochem. 27: 287-296.

WIERZBICKA M., 1987a. Lead translocation and localization inAllium cepa roots. Can. J. Bot. 65: 1851-1860.

WIERZBICKA M., 1987b. Lead accumulation and its translocation barriers in roots of Allium cepa L. - autoradiographic and ultrastructural studies. Plant, Cell and Environment 10: 17-26. 


\section{ZAWARTOŚĆ METALI CIĘŻKICH ORAZ ICH LOKALIZACJA W MIKORYZACH EUPHORBIA CYPARISSIAS L. Z HAŁDY HUTY CYNKU W POLSCE POŁUDNIOWEJ}

\section{STRESZCZENIE}

Rozwój mikoryzy arbuskularnej, zawartość metali ciężkich w roślinie oraz lokalizacja metali w komórkach E. cyparissias oraz w strzepkach grzybni przebadana została w materiale zebranym na hałdzie huty cynku w Chrzanowie oraz z dwóch innych stanowisk o różnej zawartości metali ciężkich w podłożu. Badania nad lokalizacją metali ciężkich prowadzone były wstępnie za pomocą mikroskopu świetlnego, przy zastosowaniu testu rodizonianowego. Uzyskane wyniki pozwoliły na selekcję materiału do badań przy zastosowaniu mikroskopii skaningowej i technikę EDS. Zastosowanie obu metod pozwoliło na stwierdzenie wyraźnych różnic w akumulacji metali ciężkich w ścianach grzybni. Około $80 \%$ grzybni wewnątrz korzeni cechowała wysoka zawartość metali ciężkich podczas gdy w pozostałej części nie stwierdzono ich występowania. Grzybnia pierwszego typu tworzyła nieco mniej arbuskul. Występowanie metali ciężkich stwierdzono również w ścianach komórkowych epidermy, we włośnikach oraz w krystaloidach zdeponowanych w laktiferach i komórkach kortykalnych (w bezpośrednim sąsiedztwie grzybni mikoryzowej). Badania za pomocą EDS wykazały, że krystaloidy zawierały znacznie wyższe stężenia Zn aniżeli pozostałe struktury w obrębie badanych mikoryz.

SŁOWA KLUCZOWE: mikoryza arbuskularna, pobór pierwiastków, Euphorbia cyparissias L., metale ciężkie, hałdy przemysłowe. 